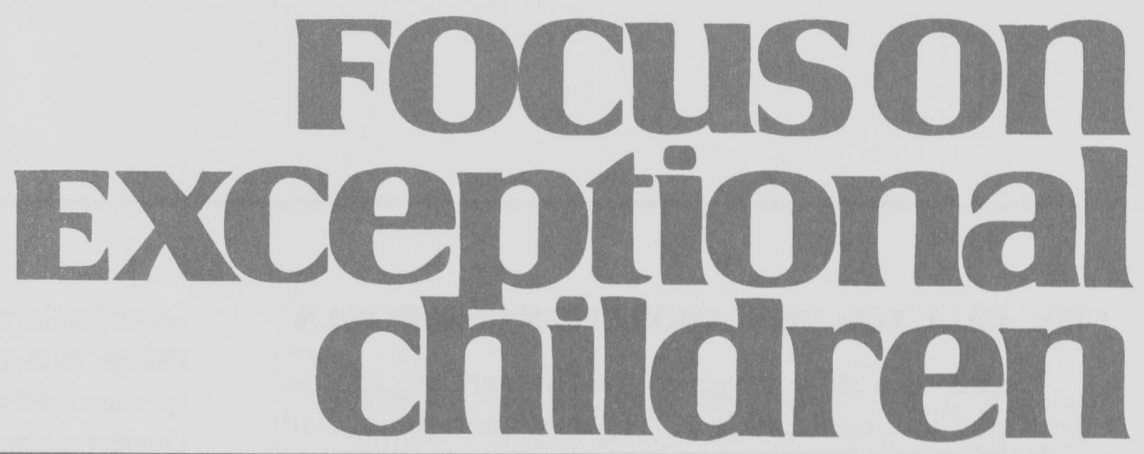

\title{
The Call for Collaboration in Teacher Education
}

\author{
Judith Winn and Linda Blanton
}

\begin{abstract}
Neither general nor special education alone has either the capacity or the vision to challenge and change the deep-rooted assumptions that separate and track children and youths according to presumptions about ability, achievement, and eventual social contribution. Meaningful change will require nothing less than a joint effort to reinvent schools to be more accommodating to all dimensions of human diversity. (Ferguson, 1995, p. 285)
\end{abstract}

As the number of students who are struggling in schools grows, the need for general and special education to come together to create the vision and capacity to educate all students becomes more and more pronounced. Collaboration by teachers is called for in the schools; likewise, it is called for in teacher education. General and special education teachers' traditional isolation from each other can be, and has been, a barrier to working collaboratively to reconceptualize schooling for all learners. This isolation can be seen as beginning with and perpetuated by parallel, noncollaborative teacher education programs. Collaboration between general and special education in teacher education programs- the dialogues, the examination of what should be taught, the rethinking of practicum experiences for teachers, the sharing of knowledge and expertise, the faculty modeling —all have high potential to support teachers' ability to work together for meaningful change.

In this article, we first explore the call for collaboration in schools - challenges to practices traditionally associated with separate general and special education, and the major current response to these difficulties-inclusive schools and classrooms. Second, we explore the larger educational context in which these collaborations are situated. In the discussion of the context of collaboration in the schools and in higher education alike, we consider the role of reform, changes in standards and accountability, and expanded views of teaching and learning. Finally, we consider the challenges teacher educators face as they work together to develop and implement collaborative teacher education programs.

Judith Winn is an associate professor in the Department of Exceptional Education in the School of Education at University of Wisconsin-Milwaukee. Linda Blanton was formally the director of the School of Education at James Madison University and is now the dean of the College of Education at Florida International University. This article was adapted from a chapter in their book, coedited with Cynthia C. Griffin and Marleen C. Pugach, entitled Teacher Education in Transition, published by Love Publishing Company. 


\section{THE CALL FOR COLLABORATION IN SCHOOLS}

Teacher education programs must prepare teachers for their roles in schools while at the same time working with schools to understand and define these roles to best facilitate the success of diverse learners. In so doing, teacher education needs to be responsive to the challenges that teachers face in the increasingly complex context of schools as well as the ways in which these challenges are beginning to be addressed. At all grade levels, the range of student performance is widening. Teachers are challenged to provide appropriate instruction for students who are working at many different levels and who are often from many different cultural and linguistic backgrounds. Additionally, teachers are challenged by the large numbers of students who are failing and dropping out of schools before graduation. This challenge is exacerbated by the pressure from the community for instruction that results in higher standardized test scores.

Coupled with the complexities of a changing student population is the increasing numbers of students being labeled for special education (U.S. Department of Education, 1995). Overrepresentation of students of color in

\section{FOCuson Exceptional children}

ISSN 0015-511X

FOCUS ON EXCEPTIONAL CHILDREN (USPS 203-360) is published monthly except June, July, and August as a service to teachers, special educators, curriculum specialists, administrators, and those concerned with the special education of exceptional children. This publication is annotated and indexed by the ERIC Clearinghouse on Handicapped and Gifted Children for publication in the monthly Current Index to Journals in Education (CIJE) and the quarterly index, Exceptional Children Education Resources (ECER). The full text of Focus on Exceptional Children is also available in the electronic versions of the Education Index. It is also available in microfilm from Xerox University Microfilms, Ann Arbor, MI. Subscription rates: individual, \$36 per year; institutions, $\$ 48$ per year. Copyright (C) 2005, Love Publishing Company. All rights reserved. Reproduction in whole or part without written permission is prohibited. Printed in the United States of America. Periodical postage is paid at Denver, Colorado. POSTMASTER: Send address changes to:

Love Publishing Company Executive and Editorial Office P.O. Box 22353

Denver, Colorado 80222

Telephone (303) 221-7333

Susan T. Warhover Editor
Stanley F. Love Publisher special education (Artiles \& Trent, 1993; Grossman, 1995; Heller, Holtzman, \& Messick, 1982; Pugach, 1995) is still another contributing factor to this complex school context. ${ }^{1}$ Overrepresentation raises issues about the lack of attention given to developing appropriate learning experiences for a wide range of students within general education. Likewise, misclassification of students, a particular problem in urban schools (Gottlieb, Alter, Gottlieb, \& Wishner, 1993), can result in students being unnecessarily stigmatized and perpetuates blaming students, rather than searching for, and supporting, instructional changes within general education programs.

Educators are called upon to question why more students are not experiencing success in general education classrooms and to work together to make changes in these classrooms so that they will. Both special and general educators are part of the school context and, thereby, contribute to how successful or unsuccessful school practices will be. Both special and general educators contribute to the current problems of misclassification and overrepresentation of students of color in special education, as both participate in the referral and assessment processes. Similarly, both special and general educators must address the challenges that these problems have begun to create. Many of these challenges are germane to collaboration and, very simply, general and special education teachers need to work together. To do this, all teachers need common frameworks for viewing and accommodating differences and this is where teacher preparation must play a central role.

Teachers need common frameworks for addressing the needs of students who are struggling - students who often are pulled out of the general education classroom for instruction in resource rooms. Concerns have been raised about pull-out programs, even for students who are labeled correctly as having special education needs. The concerns center on lack of connectedness with classroom instruction, emphasis on low-level skills, lack of focused instruction, and stigmatization of students (Allington \& McGillFranzen, 1989; Haynes \& Jenkins, 1986; McGill-Franzen \& Allington, 1991). Within a reliance on pull-out programs, students who most need continuity are those whose programs are highly fragmented. For example, students who are pulled out may be receiving instruction in the classroom based on one conception of reading, and instruction in the

\footnotetext{
${ }^{1}$ Although the proportion of minority students in special education differs from state to state, Hispanic and Native American students generally tend to be overrepresented in learning disability programs, Asian American students tend to be overrepresented in programs for speech impairments, and African American students are overrepresented in several disability areas especially mild developmental disabilities (Grossman, 1995).
} 
resource room based on a competing conception. Instruction in special education settings too often lacks attention to students' developing strategic approaches to their work, an area of particular concern for students who are experiencing difficulties (Paris \& Oka, 1986).

These concerns about the character and quality of instruction also have been raised about instruction in general education, particularly the instruction provided for students who are low achievers. Classroom observation studies have shown that practices such as time spent in actual reading, the predominance of teacher questions rather than student discussion, and the lack of attention to instruction for strategic learning are issues in both fields (Blanton \& Blanton, 1994; Goodlad, 1990; McGill-Franzen \& Allington, 1991). Overall, there is concern that curriculum and instruction for students who are struggling, in both special and general education classes, are focused too heavily on basic skills and too little on providing opportunities for reasoning and critical thinking.

General education has begun to implement changes in curriculum and instruction that make classrooms more accommodating for students who historically have been unable to succeed. Approaches based in social constructivist theory such as whole language, instruction for strategic learning, and cooperative learning emphasize the development of learners who are self-directed, able to identify problems and approach them in goal-directed ways, and profit from collaborating with others. Some special educators have shown interest in, and success with, these approaches with students labeled as having special needs (e.g., Englert, Raphael, Anderson, Anthony, \& Stevens, 1991; Lyons \& Beaver, 1995; Palincsar \& Klenk, 1992; Slavin, 1996; Stires, 1991). Students with identified special needs, as well as other students who are struggling, have been found to benefit, as seen in their achievement and interest in learning (e.g., Allington \& Wamsley, 1995). Overall, many of the changes in curriculum and instruction, and the manner in which they are carried out (e.g., student choice, explicitness about how to learn, small-group work, assessment based in the curriculum), allow for success for a wider range of students than do practices associated with more traditional general education curriculum and instruction.

Students who are struggling may need more explicit and guided instruction than other students; however, this kind of adaptation can be linked directly to accommodating general education curriculum and instruction rather than being separate from them. Even within this context, however, some students with special learning needs require more intensive instruction (Pugach, 1995). These students may be those with low-incidence disabilities, and those with more prevalent disabilities. Increasingly, new intensive instructional approaches are being developed and implemented with success (e.g. Clay, 1993; Hiebert, 1994; Taylor, Strait, \& Medo, 1994).

Similar to classroom-wide approaches such as cooperative learning, intensive approaches are found to be effective with students who are labeled as having special needs or who are being considered for referral, in some cases eliminating the need for special services (e.g., Hiebert, 1994; Lyons \& Beaver, 1995; see review by Slavin, 1996). If intensive instruction is considered "not as a last resort, but as a naturally occurring component of a healthy classroom community" (Pugach \& Seidl, 1996), more students can truly be a part of such communities rather than fragmented from their peers. Conceptualizing intensive instruction as a part of classroom communities, linking it to more general instruction, and implementing classroom-wide curriculum and instruction that is more accommodating to a wide range of students requires special and general education teachers to develop a common framework from which to view curriculum and instruction in the first place - a framework that must be set in teacher education programs.

Problems with current practices, and the successful efforts to address the problems, indicate that improving students' school experiences occur best through partnerships between special and general education at all levels, including teacher education. These partnerships are needed particularly as we work to improve school experiences of students through inclusion of students with special needs in general education classrooms and schools.

\section{Inclusion}

Inclusion of students with special needs in general education classes and schools is becoming more prevalent (e.g., Educational Leadership, Nov/Dec, 1994). In more and more schools, the entire school faculty is accepting responsibility for all students. Although there is disagreement about the proper extent of inclusion (e.g., see Fuchs \& Fuchs, 1994; Roberts \& Mather, 1995; Stainback, Stainback, \& Ayres, 1996), especially regarding issues such as retention of a continuum of placement settings, greater numbers of students with special needs are in fact being served in general education classrooms (U.S. Department of Education, 1995).

Inclusion demands many changes in schools. One of these involves changes in teachers' roles. Although teachers' roles in inclusive schools and classrooms are still evolving (Gable, McLaughlin, Sindelar, \& Kilgore, 1993) and will vary in terms of specific settings and student populations, job descriptions for special and general education teachers already look very different from those of 20 or even 10 years ago. For example, teachers are more often co-planning and co-teaching, working together to directly instruct students with and without disabilities, and assessing their learning in multiple ways. Working in inclusive classrooms does not 
necessarily mean all teachers will have the same roles; teams are enriched by members having different strengths and duties (Ford, personal communication, November 20, 1995). It does mean, however, that links must be closer than in the past, links that are forged in a common understanding of students, of teaching and learning, and of the work of all team members.

Along with changing roles, inclusive classrooms and schools require changes in curriculum and instruction. As has been noted (e.g., Keogh, 1988), "business as usual" in general education classes is not likely to benefit students with disabilities. Advocates of inclusion have been adamant that success demands changes in, rather than adaptation of, traditional curriculum and instruction (Ferguson, 1995; Pugach \& Warger, 1996; National Association of State Boards of Education, Study Group of Special Education, 1992). Best practices have been defined as:

- being grounded in an understanding of child development, subject matter knowledge, and developmentally appropriate approaches

- fostering students' pursuing and demonstrating knowledge in a variety of ways and at a variety of levels

- attending to and building on the social nature of learning providing opportunities for more intensive instruction for students who need it-students both with and without disabilities (Pugach \& Seidl, 1995; Zemelman, Daniels, \& Hyde, 1993).

One of the major challenges regarding inclusion is the need for general and special education to work together to develop curriculum and instruction based on the characteristics of best practices and which, by their nature, are more accommodating to the needs of diverse learners, including those with special needs, than programs traditionally associated with either general or with special education.

While general education traditionally has focused on curriculum development and implementation with limited attention to instruction based on individual differences, special education, especially for students with mild disabilities, has focused on instructional adaptations without a rich understanding of curriculum (Pugach \& Warger, 1995). To develop and implement curriculum and instruction based on best practices, along with appropriate instructional adaptations-adaptations that some students will still need-all teachers need grounding in curriculum and instruction for individual differences, as well as an understanding of the interconnectedness between the two. With this understanding, teachers will be able to develop supports for students who need them, rooted in, and clearly related to-rather than fragmented from - the classroom curriculum.
Critical to taking on new roles and jointly developing and implementing curriculum for inclusive schools and classrooms is the development of shared beliefs about students, teaching, and learning by general and special educators. Beliefs influence the goals of schooling, views of the teaching and learning process, curriculum and instructional choices, and ways in which teachers work together (e.g., Kagan, 1992). Effective collaboration that supports equitable opportunities for all students cannot occur if teachers have different beliefs about children and learning and about teachers' responsibilities in relation to students in both general and special education. Inclusion is supported when both general and special education teachers share the same perspective, when they view students from a diversity rather than a deficit perspective, hold high expectations for all students rather than lowered ones for some, and commit to shared rather than divided responsibility for students-all of which challenge assumptions associated with inequitable opportunities for some students. These shared beliefs form the foundation for schools in which "all teachers would be expected to teach children and to assist each other in meeting the individual students' needs" (Lilly, 1989, p. 147).

In the end, the movement toward inclusive schools and classrooms is really a response to concerns that have been raised by special and general educators alike about the value and effectiveness of practices associated with separate special education and traditional remedial programs, as well as a response to concerns about the ways in which students who are struggling are viewed. Increasingly, general and special education teachers are working collaborativelyassuming new roles, sharing and developing expertise in providing curriculum and instruction that offers equitable opportunities for a wide range of learners, and in doing so, challenging long-held assumptions. Concurrently, long-held assumptions underlying separate teacher education programs are being challenged, and faculty in both general and special education are being called on to assume new roles and share and develop new curriculum and instruction to support and facilitate what is occurring in schools.

Like collaboration in the schools, collaboration in teacher education is expanding. Twenty years ago, when Public Law 94-142 (The Education for All Handicapped Children Act) was implemented, the integration of general and special education garnered only marginal interest. In teacher education, the Dean's Grants projects were the one activity that addressed collaboration at the teacher education level. These projects achieved little success in integrating programs and, instead, attended mostly to appending special education content to existing general teacher education curricula (Pugach, 1992). In the 15 years since these projects ended, however, the context has changed as a result of reform movements, standards, and new views of teaching 
and learning. These changes have set the stage for a different kind of collaboration in the schools and in teacher education.

\section{THE CONTEXT FOR COLLABORATION IN TEACHER EDUCATION}

The context is ripe for collaboration in teacher education. We first consider school reform movements that have brought forth new visions for schools, leading to changing roles for teachers and subsequent reform in teacher education. Second, we examine the setting of standards for curriculum and assessment systems. Third, we review the ways in which teaching and learning have expanded and changed the course of research and practice in both arenas.

\section{School Reform and Teacher Education Reform}

General education school reform has been characterized by a series of phases, often referred to as waves (Rowan, 1990). These waves in school improvement over the last two decades have been based on the most current knowledge and research about teaching. During this time the research literature has changed from a dominant view of teaching as routine and mechanistic, requiring reforms that control and monitor, to views of teaching as nonroutine and complex and requiring teacher judgment and expertise (Rowan, 1990). This latter view led to reforms that heightened teachers' involvement in decision making and placed more emphasis on decentralized school structures. Currently, in what some refer to as a third wave of reform, the "restructuring" movement calls for changing the fundamental core of schooling (Prestine \& Bowen, 1993).

At the heart of this restructuring movement lie themes and innovations such as (a) local autonomy, discretion, control, (b) collaborative communities, (c) site-based management, and (d) teaming (Newmann, 1993). According to Newmann, however, these innovations may not be sufficient to improve education. Consequently, he calls for an agenda that seeks a higher level of commitment and competence from teachers and school administrators. For teachers, as an example, "the most important new forms of commitment and competence" (p. 6) are clustered in the following themes: (a) depth of understanding and authentic learning, (b) success for all students, (c) new roles for teachers, and (d) schools as caring communities. Similarly, other writers speak strongly to the need to look beyond what might be called "superficial reforms" (e.g., simply engaging in the act of moving from tracking to heterogeneous grouping) and address basic tenets, principles, and contexts that underlie reform and actually may lead to real school improvement (e.g., Goodman, 1995; Tyack \& Tobin, 1994).
Clearly, the restructuring discourse highlights key elements needing consideration in the transformation of schools. Many of these same key elements have been the focus of reports and dialogue on teacher education improvement (Sikula, 1990). Calls for changes in teacher education programs have been stimulated by a growing knowledge base about learning, teaching, and teacher education. In addition, the authority of accrediting and licensing bodies, and of state legislatures and state boards of education, has been a force to which teacher education has responded. The resulting changes in teacher education programs have included:

- incorporating the new knowledge of teaching and learning in curricula for preservice teachers

- providing opportunities for preservice teachers to work in diverse settings

- working in partnerships with schools to establish professional development schools (Darling-Hammond \& Cobb, 1996).

In Tomorrow's Schools of Education, the most recent report of the Holmes Group (1995), the authors place professional development schools at the very center of teacher education reform. According to this group, only through these partnerships will reform take place simultaneously in teacher education and in the nation's schools. Other reform models also support the importance of professional development schools in teacher education reform (Darling-Hammond \& Cobb, 1996).

In the 1980s, when much of the major reform effort was under way in general education, special education was experiencing its own reform movement. Because special education had evolved into a separate, parallel system in schools, reform in special education also evolved as a separate activity, with issues and concerns that differed from those in general education reform (Miller, 1990; Sailor, 1991). In recent years, however, the emphasis of general education reform on how to better serve a diverse, changing school population has brought the concerns of the two groups closer together. In the words of Sailor (1991), "This shift in emphasis in general education reform presents a window of opportunity for the emergence of a shared educational agenda" (p. 8).

\section{Standard Setting and Accountability}

Following on the heels of school and teacher education reform reports in the 1980s (e.g., A Nation at Risk, The National Commission on Excellence in Education, 1983) came a greater emphasis on standards and accountability. As summarized by Shriner, Ysseldyke, and Thurlow (1994), standards come in several forms and can be grouped in three frequently used categories: (a) content standards, (b) performance standards, and (c) delivery standards. 


\section{Content Standards}

Content standards establish a core of knowledge within a discipline (e.g., math) that is incorporated in and set up as the standard for curricula and programs. These standards, developed by experts and professional groups in specialty fields, then serve as the basis for state, and potentially national, curricula. In reference to identified students with disabilities in schools, the instructional needs of these students are more commonly being linked to a system's curriculum goals or outcomes (McLaughlin, 1995). This link places more emphasis on what students with disabilities are being taught and, by inference, increases the need for collaboration between special and general education teachers.

In teacher education, content standards most often are referred to as the body of knowledge and skills (knowledge base) expected of those who plan to practice in the teaching profession. Although many colleges and schools of education have a history of articulating their knowledge bases, the stakes became greater when the national accreditation body, the National Council for Accreditation of Teacher Education (NCATE), redesigned its standards to require a written document (Wise, 1994). In addition, NCATE has specified some elements of a knowledge base that are expected to be present in all teacher preparation programs seeking its accreditation. One requirement is that novice teachers will acquire knowledge and skills to enable them to work with diverse populations (including exceptionality). This expectation set the stage and, especially, the need for collaboration between general and special educators.

\section{Performance Standards}

Performance standards, as defined by Shriner et al. (1994), refer to the performance expected of students as a result of the application of content standards. One prime example of performance standards is statewide public school student assessment. A few states have begun to include students with disabilities in these outcome-based assessment systems (McLaughlin, 1995), which, again, suggests the need for general and special education collaboration. In teacher education, changes are occurring in teacher assessments in which the aim is to go beyond the traditional format of multiple-choice questions and include essay components, portfolios, and classroom observations. An example of such a change is the Educational Testing Service's new testing series for teachers, the Praxis (Darling-Hammond \& Cobb, 1996).

\section{Delivery Standards}

Delivery standards are standards that assure that the conditions are set for teaching and learning to occur. Two examples are state licensure for teachers and advanced certification for accomplished teachers. State licensure, which is often orchestrated by local and state politicians, is influenced currently by a consortium created by the Council of Chief State School Officers. This consortium of 28 states, the Interstate New Teacher Assessment and Support Consortium (INTASC), is working together with teachers and teacher educators to make licensing standards a reality. These licensing standards were developed from, and are compatible with, those of the National Board for Professional Teaching Standards, a group that has taken the lead in developing advanced certification for highly accomplished teachers (Darling-Hammond \& Cobb, 1996).

Both of these-licensing and advanced certification - are mechanisms for assuring quality control in the profession. The changes and trends in each of them also influence teacher preparation. As one example, the standards developed by INTASC were incorporated recently by NCATE as one way of strengthening the expectation that teacher education programs rely on a defined knowledge base and specific student outcomes (Darling-Hammond \& Cobb, 1996; Wise, 1994). These new NCATE accreditation standards require teacher education students to actually demonstrate specific skills such as "adapt instruction for culturally diverse and exceptional populations" (Wise, 1994, p. 9).

Another example of the influence of licensing and advanced certification bodies on teacher education is that these groups are drawing on the most current research on teaching and learning and are using this research to drive changes in both areas. For example, these groups have adopted the conception of "teachers as thinkers" (DarlingHammond \& Cobb, 1996). Certainly, standard setting, through accreditation, licensure, and advanced certification, is a potent force in the changes currently under way in teacher education. These major forms of quality control have established a context that strongly supports the need for general and special teacher educators to communicate about implementation of these standards.

\section{Expanded Views of Teaching and Learning}

Teaching and learning research has expanded greatly and, in some cases, taken significant turns in the last two decades. Cognitive psychology took the lead and influenced a large and growing body of research providing strong support for constructivist conceptions of learning (Prawat \& Floden, 1994; Shuell, 1986), which in turn drives many of the recent curricular and instructional changes in general education. Inquiry has shifted from a research tradition strongly influenced by behaviorism (e.g., process-product research) to research that focuses on the complexities of teaching (e.g., classroom ecology) (Shulman 1986). Much of this recent inquiry in teaching and learning relies heavily on qualitative research methodology, with lines of inquiry directed toward classroom contexts and teacher thinking 
(Barnes, 1989; Erickson, 1986; Shulman, 1986). Interestingly, these more recent forms of inquiry, used in both teaching and learning research, have been a significant departure from traditional thinking and research in special education.

Research and practice in special education have been dominated by behaviorist orientations, leading to mechanistic and procedural learner applications such as diagnosticprescriptive teaching and token economies (Colarusso, 1987). In like manner, the findings of process-product teaching research have remained dominant in special education literature (Blanton, 1992). Although we see evidence in this literature of the influence of more recent conceptions of teaching and learning, these changing paradigms seem to be slow to take hold in special education. General teacher preparation programs throughout the country have begun to consider and incorporate the newer lines of research on teaching and learning into the delivery of their curricula (e.g., Feiman-Nemser \& Featherstone, 1992; Tabachnick \& Zeichner, 1991). Similar changes may not be occurring as frequently in special education. Many programs are still dominated by a competency-based approach to teacher education (Blanton, 1992; Sindelar, Pugach, Griffin, \& Seidl, 1995). Competency-based teacher education has remained a mainstay of special education teacher education long after the approach peaked in the 1970s and long after it took a back seat to other movements in teacher education (Carter \& Anders, 1996). The emphasis on teachers' thinking and decision making in general education teacher education presents a significant challenge for many in special education teacher education. If special education is to engage in any type of collaborative activity with general teacher educators, the two fields will have to communicate about and understand the different conceptions each area holds about teaching and learning. Further, both fields must communicate about the influence of these conceptions on teacher education.

\section{COLLABORATION IN HIGHER EDUCATION}

The growth of inclusive schools and classrooms has the potential to increase the opportunities for success for a wider range of students within general education classrooms, to increase the opportunities for all students to engage in authentic and meaningful work, and to decrease unnecessary referrals to special education. General and special education teachers alike need to be prepared to work together to meet the needs of diverse learners, especially those who are struggling. To do this, teachers need to share beliefs about students, teaching and learning; to have a rich knowledge base about curriculum and instruction; and to know how to collaborate. To support teachers who can facilitate students' success in inclusive schools and classrooms, collaboration between general and special education in teacher preparation is necessary. This collaboration involves faculties in higher education sharing expertise, modeling collaboration and at the same time deepening their understanding of it and openly discussing beliefs and values. Collaboration in higher education, though it is becoming more prevalent, often faces barriers within the university and college culture.

\section{Barriers to Collaboration in Teacher Education}

The culture in universities and colleges may work against the very activity (i.e., collaboration) needed most to deliver quality programs to students with disabilities and other students whose needs are not being met. Settings develop a culture that dictates thinking and actions of those in it, and colleges and schools of education reveal artifacts of a culture that are similar from one university or college to another. We often see the same names for departments and programs, the same governance structures, and many of the same activities performed by faculty (teaching, research, and service) across institutions. These similarities are an outgrowth of the structures put into place in institutions of higher education (IHE). Like other organizations, IHEs develop structures to accomplish the work of the organization (Heller, 1996). In considering these structures (e.g., departments), a number of factors emerge as barriers to integration of teacher education programs in general and special education.

Earlier we noted the basic differences between general and special teacher educators in their perspectives about teaching and learning. If we consider this in relation to the departmentalized structure of most colleges and schools of education, we can see how this segregated structure supports the professional isolation and identities of different groups. In these separate departments, the faculty works in small program groups to develop and deliver curricula for its students. In most cases, decision making about program development and other issues relating to the preparation of students is not terribly difficult because the faculty speaks a common language based on similar backgrounds and experiences of faculty members. Only occasionally do many of these individuals venture beyond these boundaries for program development purposes. When they do, they might meet more conflict because the philosophical orientations of faculty from various disciplines may differ and create communication barriers. In addition, as Lilly (1989) pointed out, professional inertia can play a role and is often manifested in common clichés such as "we've always done it this way" (p. 154).

Reward structures for faculty on university campuses usually are not set up to provide incentives for the kind of program development required for collaboration. In many institutions, particularly in research institutions, research may weigh far greater than the teaching and service areas for 
tenure and promotion (Goodlad, 1990). Even in institutions where teaching is the primary focus, rewards seem based primarily on one's individual accomplishments. Added to the emphasis on individual accomplishments is the control that faculty members have over their professional lives. Faculty in IHEs often exercise a great deal of control over schedule, course content, and grading (Heller, 1996). With this control, the faculty is in a position to refuse to follow an agenda set forth by colleagues, a department head, or a dean.

The leadership in Colleges and Schools of Education (e.g., deans, department heads) may attempt to initiate change in the organization only to face opposition from faculty. As noted, the faculty exercises a great deal of control in IHEs, in which faculty governance is often the rule. In contrast, individuals in leadership roles may not always understand and support the need for faculty collaboration in developing alternative curricula for preservice teachers. This is an important consideration if we heed the research on effective schools, which shows how important leadership is to achieving instructional goals (Lezotte, 1989).

The issue of resource allocation also can be a barrier to the integration of general and special education teacher education programs. Resources (e.g., faculty positions) usually are based on how many student credit hours a program or a department generates. Recruitment of students and accompanying resources allocated to programs often are divided along department lines. This sort of division leads naturally to competition for students and resources. In addition, people in the bureaucratic structures on many campuses are reluctant to respond to different models for allocating resources.

Despite these barriers, collaboration in teacher education is taking place, challenging norms and practices created by the structures and cultures of IHEs. As efforts such as those described in this article and elsewhere become known, we can learn about changes that are needed to support the time, commitment, and risks that collaboration in higher education entails. This knowledge, in turn, can challenge the barriers to collaboration.

\section{Learning to Collaborate}

One of the greatest benefits of collaboration in teacher education is that it can provide much needed professional development by teacher education faculty. Alone, faculty in separate departments rarely have the breadth of knowledge about curriculum and instruction on the one hand, and about individual differences on the other, needed to prepare teachers for inclusive classrooms. In addition, faculty members are likely to have limited experience with collaboration themselves, and thus limited understanding of the challenges involved. Finally, their existence within separate programs may perpetuate a lack of examination of their own assumptions and beliefs. Collaboration in teacher education, by its nature, challenges faculty members to address and enrich their own grounding. Articulation and examination of beliefs and assumptions-both those of individual faculty and those that will anchor programs - is required.

Faculty members are also challenged to assume new roles and responsibilities-joint planning of programs and courses, team teaching, sharing responsibility for a wider group of students - that in many ways parallel the roles of teachers in K-12 schools. Through collaboration, faculty members can model and at the same time come to understand the realities, benefits, and challenges of the kinds of collaboration for which they are preparing teachers. Working together at the teacher education level also can help faculty members expand their own knowledge about curriculum and individual differences and, in turn, understand and model how those with differing levels of knowledge in these areas can collaborate.

The need for collaboration in teacher education between special and general education clearly is driven by what isand is not-occurring in the schools. The challenge to rethink practices often associated with separate teacher education programs, and-to work together in inclusive settings where diversity is valued and accommodated, requires that teachers' knowledge base be expanded and, most important, that they come to share beliefs that ground their work. If we are to make changes in teacher education, we must ask ourselves if we are prepared to go beyond one perspective to guide teaching and learning, a history of traditional teacher preparation, and a history of unchanging departmental and college structures. This can happen-and it is happening in programs nationwide.

Rethinking traditional practices will continue as we increase our collaboration. As new teacher education programs develop, second generation issues inevitably will surface, and the expanding knowledge about collaborative teacher education programs will uncover yet other factors that will affect future collaborations. We will continue to learn from each other, as well as from our partners in schools, as we take on the critical task of developing teacher education programs that prepare teachers to provide equitable learning experiences for today's and tomorrow's diverse learners.

\section{REFERENCES}

Allington, R. L., \& McGill-Franzen, A. (1989). Different programs, indifferent instruction. In A. Gartner \& D. Lipsky (Eds.), Beyond separate education: Quality education for all (pp. 75-98). Baltimore: Paul Brookes.

Allington, R. L., \& Wamsley, S. A. (Eds.). (1995). No quick fix. New York: Teachers College Press. 
Artiles, A. J., \& Trent, S. C. (1993). Overrepresentation of minorities in special education: A continuing debate. Journal of Special Education, 27, 410-537.

Barnes, H. (1989). Structuring knowledge for beginning teaching. In M. C. Reynolds (Ed.), Knowledge base for the beginning teacher (pp. 13-22). New York: Pergamon Press.

Blanton, L. P. (1992). Preservice education: Essential knowledge for the effective special education teacher. Teacher Education and Special Education, 15, 87-96.

Blanton, L. P., \& Blanton, W. E. (1994). Providing reading instruction to mildly disabled students: Research into practice. In K. D. Wood \& B. Algozzine (Eds.), Teaching reading to high-risk learners (pp. 9-48). Needham Heights, MA: Allyn \& Bacon.

Carter, K., \& Anders, D. (1996). Program pedagogy. In F. B. Murray (Ed.), The teacher educator's handbook: Building a knowledge base for the preparation of teachers (pp. 557-592). San Francisco: Jossey-Bass Publishers.

Clay, M. M. (1993). Reading recovery: A guidebook for teachers in training. Portsmouth, NH: Heinemann.

Colarusso, R. P. (1987). Diagnostic-prescriptive teaching. In M. C. Wang, M. C. Reynolds, \& H. J. Walberg (Eds.), Handbook of special education research and practice: Vol. 1. Learner characteristics and adaptive education (pp. 155-166). New York: Pergamon Press.

Darling-Hammond, L., \& Cobb, V. L. (1996). The changing context of teacher education. In F. B. Murray (Ed.), The teacher educator's handbook: Building a knowledge base for the preparation of teachers (pp. 14-62). San Francisco: Jossey-Bass Publishers.

Educational Leadership, Nov./Dec. 1994.

Englert, C. S., Raphael, T. E., Anderson, H. M., Anthony, H., \& Stevens, D. D. (1991). Making strategies and self-talk visible: Writing instruction in regular and special education classrooms. American Educational Research Journal, 28, 337-372.

Erickson, F. (1986). Qualitative methods in research on teaching. In M. C. Wittrock (Ed.), Handbook of research on teaching (pp. 119-161). New York: Macmillan.

Feiman-Nemser, S., \& Featherstone, H. (Eds.) (1992). Exploring teaching: Reinventing an introductory course. New York: Teachers College Press.

Ferguson, D. L. (1995). The real challenge of inclusion: Confessions of a "Rabid inclusionist." Phi Delta Kappan, 77, 281-287.

Fuchs, D., \& Fuchs, L. (1994). Inclusive schools movement and the radicalization of special education reform. Exceptional Children, 60, 294-309.

Gable, R. A., McLaughlin, V. L., \& Sindelar, P., \& Kilgore, K. (1993). Unifying general and special education: Some cautions along the road to educational reform. Preventing School Failure, 37(2), 5-10.

Goodlad, J. I. (1990). Teachers for our nation's schools. San Francisco: Jossey-Bass Publishers.

Goodman, J. (1995, April). Change without difference: School restructuring in historical perspective. Harvard Educational Review, 65(1), 1-29.

Gottlieb, J., Alter, M., Gottlieb, B. W, \& Wishner, J. (1993). Special education in urban America: It's not justifiable for many. Journal of Special Education, 27, 453-465.

Grossman, H. (1995). Special education in a diverse society. Boston: Allyn \& Bacon.

Haynes, M. C., \& Jenkins, J. R. (1986). Reading instruction in special education resource rooms. American Educational Research Journal, 23, 161-190.
Heller, H. W. (1996). A rationale for departmentalization of special education. In W. Stainback \& S. Stainback (Eds.), Controversial issues confronting special education: Divergent perspectives (2d ed., pp. 253-263). Boston: Allyn \& Bacon.

Heller, K. A., Holtzman, W. H., \& Messick S. (Eds.). (1982). Placing children in special education: A strategy for equity. Washington, DC: National Academy Press.

Hiebert, E. H. (1994). A small group literacy intervention with Chapter 1 students. In E. H. Hiebert \& B. M. Taylor (Eds.), Getting reading right from the start: Effective early literacy interventions (pp. 85-106). Boston: Allyn \& Bacon.

Holmes Group. Tomorrow's schools of education: A report of the Holmes Group. (1995). East Lansing, MI: Holmes Group.

Kagan, D. M. (1992). Implications of research on teacher beliefs. Educational Psychologist, 27(1), 65-90.

Keogh, B. (1988). Extending services for problem learners: Rethinking and restructuring. Journal of Learning Disabilities, 21, 19-22.

Lezotte, L. W. (1989). School improvement based on the effective schools research. In D. K. Lipsky \& A. Gartner (Eds.), Beyond separate education: Quality education for all (pp. 25-37). Baltimore: Paul H. Brookes Publishing.

Lilly, M. S. (1989). Teacher preparation. In D. K. Lipsky \& A. Gartner (Eds.), Beyond separate education: Quality education for all (pp. 143-157). Baltimore: Paul H. Brookes Publishing.

Lyons, C. A., \& Beaver, J. (1995). Reducing retention and learning disability placement through Reading Recovery: An educationally sound, cost-effective choice. In R. A. Allington \& S. A. Wamsley (Eds.), No quick fix: Rethinking literacy in America's elementary schools (pp. 116-136). New York: Teachers College Press.

McGill-Franzen, A., \& Allington, R. L. (1991). The gridlock of low reading achievement: Perspectives on practice and policy. Remedial and Special Education, 12(3), 20-30.

McLaughlin, M. J. (1995). Defining special education: A response to Zigmond and Baker. Journal of Special Education, 29, 200-208.

Miller, L. (1990). The regular education initiative and school reform: Lessons from the mainstream. Remedial and Special Education, 11(3), 17-22, 28.

National Association of State Boards of Education Study Group on Special Education (1992). Winners all. Alexandria, VA: NASBE.

National Commission on Excellence in Education. (1983). A nation at risk. Washington, DC: National Commission on Excellence in Education.

Newmann, F. M. (1993). Beyond common sense in educational restructuring: The issues of content and linkage. Educational Researcher, 22(2), 4-13, 22.

Palincsar, A. S., \& Klenk, L. (1992). Fostering literacy learning in supportive contexts. Journal of Learning Disabilities, 25, 211-225.

Paris, S., \& Oka, E. (1986). Self-regulated learning among exceptional children. Exceptional Children, 53, 103-108.

Prawat, R. S., \& Floden, R. E. (1994). Philosophical perspectives on constructivist views of learning. Educational Psychology, 29(1), 37-48.

Prestine, N. A., \& Bowen, C. (1993). Benchmarks of change: Assessing essential school restructuring efforts. Educational evaluation and policy analysis, 15, 298-319.

Pugach, M. C. (1992). Unifying the preservice preparation of teachers. In W. Stainback \& S. Stainback (Eds.), Controversial issues confronting special education: Divergent perspectives (pp. 255-269). Boston: Allyn and Bacon. 
Pugach, M. C. (1995). Twice victims: The struggle to educate children in urban schools and the reform of special education and Chapter 1. In M. C. Wang \& M. C. Reynolds (Eds.), Making a difference for students at risk: Trends and alternatives (pp. 27-60). Thousand Oaks, CA: Corwin Press.

Pugach, M., \& Seidl, B. (1995). From exclusion to inclusion in urban schools: A new case for teacher education reform. Education and Urban Society, 27, 379-395.

Pugach, M., \& Seidl, B. (1996). Deconstructing the diversity-disability connection. Contemporary Education, 68(1).

Pugach, M. C., \& Warger, C. L. (1995). Curriculum considerations. In J. I. Goodland \& T. C. Lovitt (Eds.), Integrating general and special education (pp. 125-148). New York: Macmillan.

Pugach, M. C., \& Warger, C. L. (1996). Curriculum trends, special education, and reform: Refocusing the conversation. New York: Teachers College Press.

Roberts, R., \& Mather, N. (1995). The return of students with learning disabilities to regular classrooms: A sellout? Learning Disabilities Research and Practice, 10(1), 46-58.

Rowan, B. (1990). Commitment and control: Alternative strategies for the organizational design of schools. In C. B. Cazden (Ed.), Review of research in education (pp. 353-389). Washington, DC: American Educational Research Association.

Sailor, W. (1991). Special education in the restructured school. Remedial and Special Education, 12(6), 8-22.

Shriner, J. G., Ysseldyke, J. E., \& Thurlow, M. L. (1994). Standards for all American students. Focus on Exceptional Children, 26(5), 1-19.

Shuell, T. J. (1986). Cognitive conceptions of learning. Review of Educational Research, 56, 411-436.

Shulman, L. S. (1986). Paradigms and research programs in the study of teaching: A contemporary perspective. In M. C. Wittrock (Ed.), Handbook of research on teaching (pp. 3-36). New York: Macmillan.

Sikula, J. (1990). National commission reports of the 1980s. In W. R. Houston (Ed.), Handbook of Research on Teacher Education (pp. 72-82). New York: Macmillan Publishing.
Sindelar, P. T., Pugach, M. C., Griffin, C. C., \& Seidl, B. L. (1995). Reforming teacher education: Challenging the philosophy and practices of educating regular and special educators. In J. L. Paul, H. Rosselli, \& D. Evans (Eds.), Integrating school restructuring and special education reform (pp. 140-166). New York: Harcourt Brace.

Slavin, R. (1996). Neverstreaming: Preventing learning disabilities. Educational Leadership, 53(5), 4-7.

Stainback, S., Stainback, W., \& Ayres, B. (1996). Schools as inclusive communities. In W. Stainback \& S. Stainback (Eds.), Controversial issues confronting special education: Divergent perspectives (pp. 31-43). Boston: Allyn \& Bacon.

Stires, S. S. (Ed.). (1991). With promise. Portsmouth, NH: Heinemann.

Tabachnick, B. R., \& Zeichner, K. M. (Eds.). (1991). Issues and practices in inquiry-oriented teacher education. New York: Falmer Press.

Taylor, B. M., Strait, J., \& Medo, M. A. (1994). Early intervention in reading: Supplemental instruction for groups of low-achieving students provided by first-grade teachers. In E. H. Hiebert \& B. M. Taylor (Eds.), Getting reading ready right from the start: Effective early literacy interventions (pp. 107-121). Needham Heights, MA: Allyn \& Bacon.

Tyack, D., \& Tobin, W. (1994). The "grammar" of schooling: Why has it been so hard to change? American Educational Research Journal, 31, 453-479.

U.S. Department of Education. (1995). Seventeenth annual report to Congress on the implementation of the Individuals with Disabilities Education Act, Washington, DC: Government Printing Office.

Wise, A. (1994). The coming revolution in teacher licensure: Redefining teacher preparation. Action in Teacher Education, 16(2), 1-13.

Zemmelman, S., Daniels, H., \& Hyde, A. (1993). Best practice: New standards for teaching and learning in America's schools. Portsmouth, NH: Heinemann. 


\section{SPECIAL EDUCATION}

POLICY AND PRACTICE

\section{Accountability, Instruction, and Social Challenges}

Thomas M. Skrtic

Karen R. Harris

James G. Shriner

This is an excellent book that addresses the policy shift in special education from procedural compliance to standards-based accountability and the changing conditions of practice under reform. It covers the major problems of implementing reform and presents several practices and models to improve the conditions of special education practice.

The authors support a collaborative environment for service delivery and inclusive work atmospheres with research-based instructional practices. The book gives prevention and intervention strategies including specific reading, writing, and mathematics instructional techniques. Other topics include transition, selfdetermination, school violence, health needs, and literacy instruction for Latino students.

The focus in the last part of the book is oriented to human needs and opportunities that will shape special education practice in the future including individual and environmental conditions. These include welfare of children working across social contexts and providing a planning framework for achieving integrated services.

0401 / Paperback / 582 pages / ISBN 0-89108-310-3 / \$68.00

Love Publishing Company

9101 E. Kenyon Ave., Suite 2200

Denver, CO 80237

$303-221-7333 \cdot 303-221-7444$ (fax) 


\section{Professional update}

Learning Disabilities Association

International Conference

February 26-March 1, 2006

Jacksonville, Florida

Contact: National Headquarters

(412) $341-1515$

\section{Council for Exceptional Children} Annual Convention and Expo

April 5-8, 2006

Salt Lake City, Utah

Contact: www.cec.sped.org
National Association of School Psychologists Annual Conference

March 28-April 1, 2006

Hilton Anaheim Hotel / Anaheim, California

Contact: NASP

(301) 657-0270

American Educational Research Association Annual Conference

April 8-12, 2006

San Francisco, California

Contact: www.aera.net 